\title{
PROPOSED REVISION OF THE RULES OF COURT*
}

\section{S. J. HELMAN‡}

The Benchers of the Law Society of Alberta decided that in view of the many years which had elapsed since the last revision of the rules of court of this Province had been undertaken that the rules should again be reviewed. To that end the Benchers engaged S. W. Field, Esq. Q.C. and appointed J. J. Saucier, Esq. Q.C. and the writer to consult with him and make such suggestions as we thought advisable. $\mathrm{Mr}$. Field reconsidered our present rules in the light of the experience of their operation for more than fifteen years and compared them with the English and Ontario rules and the Federal Civil Code. The recommendations have been put forward for the study and comments of the Bar of Alberta.

The rules of court are the working tools of the lawyer insofar as litigation is concerned and they therefore must enable a lawyer to get his case before a judge without any unnecessary difficulty.

One of the purposes of a procedural system is to delimit the area of controversy and to focus the litigation upon matters which are likely to dispose of the case. Another purpose is to bring about the disclosure and presentation at trial of all relevant evidence.

Modern procedure should aim to do away, as far as possible, with the present practice of the marshalling by each side of his forces for the day of trial behind a screen which the other party may not penetrate. In an article Mr. Justice Ruttan of the Supreme Court of British Columbia refers to a statement by an eminent jurist regarding what he called "the sporting theory of justice, a theory that stresses the law suit as a game with a judge as an umpire awarding the prize to the more skilful" and the same learned jurist is further quoted as saying "This principle is outmoded. We all now see in a lawsuit a means to achieve justice under the law".

It is also hoped that by the proposed revision costs will be saved by doing away with unnecessary proof and procedural steps.

In 1938 the U.S. Federal rules were adopted and they now govern the practice not only in the Federal Courts but in the State courts in over half the States. These rules resulted from much study and at a bound they wiped out the hitherto archaic and cumbersome procedure which had been in force in the Federal Courts. The chief architect of the Federal Rules was Charles E. Clark.' The Federal Rules, in the writer's view, constitute the most liberal and effective code of procedure to be found anywhere.

It is now proposed to set out the revisions proposed by $\mathrm{Mr}$. Field and to add comments (in brackets) only where additional information is felt to be necessary. It is helpful in order to understand fully the proposed changes to have the Alberta rules of court before you.

- A paper dellvered to The Law Soctety of Alberta and revised for publication.

ISamuel J. Helman, Q.C. of the Alberla Bar. Calgary.

Charles E. Clark, LL.B.. LL.D. New Haven, Conn., Chicf Judse of the United States Court of Appeals. Sccond Circuit, from 1954 to 1959. has been a United States Circuit Judse since 1039. Before that he was Dean of the Yale Law School and Sterling Professor of low at Yale. He served as Reporter to and member of the Supreme Court's Advisory Committee on Rules of Clvil Procedure throughout Its existence 1935-1955 and hence was the princlnal draftsman of the Federal Rules of Clvil Procedure. 


\section{PROPOSED REVISIONS}

1. a-The Rules now refer to "The Court", "The Court or a Judge" or "A Judge". In the next revision, the reference should be in all cases to "The Court" and the Definitions Section should be modified to indicate that "The Court" includes a local judge or Master in Chambers acting within this jurisdiction.

$\mathrm{b}$-Either one of two Masters in Chambers should be appointed who should also act as Official Referees. This would relieve the judges of the heavy burden of Chamber work, would ensure that Chamber Applications receive proper consideration, and would tend to make the practice uniform.

2. Service.

a-There is no provision in the Rules for service upon a person who is not of unsound mind but who is unable to handle his own affairs. Where there has been a person appointed to handle them, in addition to service upon such person, the public trustee should be served.

b-Rule 31 is incorrectly placed and should be embodied in Rule 19 .

c-Rule 15

The Rule which provides that the time for service of a Statement of Claim can only be extended by an order made before the expiry of the year limited for service should be amended and provision made that in a proper case, an order could be made after the expiry of the year. This Rule has worked great hardship on solicitors who have overlooked the time for service, and there appears to be no corresponding advantage in retaining it in its present form.

3. Service Ex Juris (Rule 34 and 35)

a-The English Rules provide, in addition to the cases in which service is permitted by our Rules, for service ex-juris when the contract is made within the jurisdiction or where it expressly provides that it should be governed by the law of the jurisdiction. These provisions should be embodied in our Rules with this modification that the service should only be permitted when the contract is made in Alberta if the contract itself does not provide for its being governed by the law of other jurisdictions.

$b$-The last paragraph of the rule is very badly worded. The reference to actions on judgments should be taken out of this paragraph and service permitted in any action of the judgment. The paragraph should then be amended to provide that service should be allowed in the case of action for alimony when the defendant has assets in the jurisdiction but the judgment should not be signed without an Order of the Court.

c-There should also be a provision added that service should be permitted when a breach of contract is alleged on a contract which ought to be performed in Alberta, notwithstanding the fact that a prior breach has been committed outside the jurisdiction. This clause was inserted in the English and Ontario Rules as a 
result of the decision of the House of Lords. (The decision is Johnson v. Taylor, [1920] A.C. 144.)

d-An affidavit should also be amended by providing that the deponent should swear that in his belief the plaintiff has a good cause of action rather than that he is entitled to the relief claimed and that this is a proper case for service under the rules.

e-There should be added to the rules the provision that the defendant may serve ex-juris third party notice in any case in which he would be entitled under the rules to service upon a person resident in Alberta.

(This would fill a hiatus that presently appears in the rules as there would seem to be no machinery for service out of the jurisdiction of third party proceedings where the third party has been added by reason of matter arising from events covered by the original action and forming an essential part of it.)

4. Rule 29 should be placed after Rule 35 with a separate heading, "Set Aside Service" and should be modified to read that the defendant may at any time, before delivering a defence, move to set aside an order for service, or service, on the ground that such service was not justified by the Rules, or for irregularities, or any other ground, and that such application should not be deemed to be a submission to the jurisdiction.

5. Rule 81-et seq.

The Third Party Procedure should logically follow after the rules relating to Pleadings.

There should also be a provision that a defendant by counterclaim may avail himself of this procedure.

6. Rule $\mathbf{9 0}$ should be amended to make it clear that an action does not abate after the conclusion of the trial if judgment is reserved.

(If one of the parties to the action dies while judgment is reserved, judgment may still be delivered as if the party was still alive.)

7. Rule 109 should be modified to make it clear that a demand for notice cannot be filed in the case of a liquidated demand.

8. The Form of Commission settled sometime ago by the late Mr. Justice McBride should be added as a form in the Rules and the Rules relating to commissions amended accordingly.

9. Rule 161, dealing with Admissions and Denials in Pleadings, should be amended to read as follows:

It shall not be necessary in a pleading to deny specifically the allegations in the preceding pleading but a compendious denial shall be sufficient of those allegations which are not expressly admitted

(The present Rule 161 seems to conflict with Rule 166. Moreover, it is difficult to know what is meant by silence being "not construed as an admission of the truth of the allegation".)

10. The provision in regard to place of trial and the provision providing that the amount of damages must be specified should be added to the rules dealing with the Statement of Claim. They are now found elsewhere. 
11. Rule 165-the words "liquidated demand" should be substituted for the words "money demand".

12.Rule 260

Instead of this rule, it is recommended that the following be adopted:

a-The Court, on its own motion, or by the consent of the parties, in any case where technical evidence is required, may appoint an expert who makes a report, a copy of which is filed and given to the solicitors for all parties. This report is received for the information of the court and either party has the right to crossexamine upon it at such time during the course of the trial as the judge may direct.

b-It should be provided that the appointment of a court expert, as this expert is described, should not prevent the parties from calling their own expert.

13. Rules 259 and 260 should be amended by providing that an examining physician may ask and obtain answers as to the physical condition and medical history of the party being examined. At the present time, examinations are not as effective as they should be because of the operation of the authorities which hold that these questions cannot be asked.

(It is submitted that there should be added to the rules respecting expert evidence, and this includes medical evidence, the following which the writer has taken from the Evershed Report. ${ }^{2}$ ):

(A) No plan, model or photograph should be receivable in evidence unless at least ten days before the hearing the opposite party has been given an opportunity to inspect it.

(B) The evidence of an expert (including that of a doctor) should not be receivable unless a copy of his report has been made available for inspection by the other side at least ten days before the trial. This should also apply to experts' plans, drawings and sketches.

(C) The rules should also provide that either the Doctor appointed by the court or a doctor acting for the opposite party shall be entitled, if the court so directs, to have blood tests, $x$-rays, E.E.G. E.C.G. tests and any other tests taken which are required for purposes of diagnosis.

(D) At all medical examinations the person being examinated may have his own doctor present.

Returning to Mr. Field's proposals:

14. Production of Documents.

a-A provision should be added, similar to that in the B.C. Rules, which defines "documents" as including photographs, films, recordings of sound or other material of a permanent or semipermanent character.

Final Report of the Commlttee on Supreme Court Practise and Procedure. July 1953. Cmd. 8378. This committee consistling of some 23 members spent some slx active years under the chajrmanship of Lord Evershed, then the Master of the Rolls. It runs to 380 pages. 
b-A clause should be added which was found most useful in the older Orders for Directions to the effect that a party producing a document admits it to be the document which is purports to be unless he expressly states to the contrary.

c-There has been some difficulty experienced from the fact that reports, which are in effect purely routine reports, have been headed for the information of the solicitors in the event of litigation or with a similar heading and have therefore, been exempt from inspection. There should be a provision that notwithstanding such a heading, the Court should consider the merits of the case and decide whether in fact such documents are or are not privileged.

(Dealing with 14 (b) this suggestion does not, it is submitted, go far enough because, while the documents of the opposite party have been admitted as being authentic, it does not permit one to use one's own documents without further proof, even though the opposite party may use them as being admitted as authentic. Dealing with the documents so produced the following, which is taken from the Evershed Report in part and in part from the Resolution of the General Council of Bar in England at their 1960 meeting, would eliminate a great deal of unnecessary proof at trial.):

(E) Any document set out in the affidavits of production of either party should prima facie be deemed authentic, unless specifically challenged by notice of non-admission by the opposite party at his own peril as to costs. Such documents should be accepted as prima facie evidence of the facts stated therein to the extent that the maker of the document, if called as a witness could under the present rules of evidence give evidence of the facts contained in such documents. ${ }^{3}$

(A further simplification of proof respecting documents in the possession of third parties-again from Evershed-would be useful.):

(F) In the case of documents in the possession of a third party no witness whose sole function is to produce and prove a document should be required to attend and give evidence unless his attendance is specifically required by the opposite party for the purpose of cross-examination. The notice to the witness shall only require that the person served deliver or send the document or documents by registered post to the Clerk of the Court. A fee of $\$ 1.00^{4}$ should be enclosed with the notice to cover postage and a special envelope enclosed for that purpose. The witness may if he so desires forward a copy duly authenticated by a commisioner for oaths.

(The change advocated by Mr. Field in 14 (c) is most desirable. As stated in a recent article on "Developments in the Law-Discovery": "

Similary, when the client acts in response to suggestions by counsel for routine

3 The Peel Commission. which worked on the rules prlor to the Evershed Committee went further and advocated the following:

"The Judge should have discretion to admit all documents and records relatin to the matter in question which came into existence before the dispute arose. "Thls would put the judge in the same position as the ordinary commercjal arbitrator." + The amount of $\$ 1.00$ may not be sufflelent and two or three times that amount would

s (1961) 74 Harv. L.R. 940. 
activity-as for example, in establishing a policy of preparing reports after all accidents-the extent of the lawyer's participation seems too insignificant to warrant denial of discovery.)

15. That portion of Rule 518 which does not deal with the custody of property, the subject matter of litigation, should be placed with the rules dealing with Production and should have a separate headingProduction and Inspection of Chattels.

16. Discovery-a number of changes in these rules are suggested.

a-Rule 258 should be placed with Rule 240 and these should be provision added that the costs of more than one examination of an employee should be borne by the party examining unless the court otherwise orders.

b-Rule 250 is in conflict with Rule 254 and should be struck out. All matters should be decided by the judge.

c-Provision should be made that objection might be taken at the trial to the admissibility of any question on an examination for discovery, even if an objection has not been taken at the time of the examination. (This provision is found both in the B.C. and Manitoba Rules.)

d-Provision should be made, as in the B.C. Rules, that where an action is brought for an infant by his next friend, either the infant or the next friend can be examined for discovery if the examining officer decides that the infant is competent to be examined.

-The rules in regard to examination of officers of corporations have proven unsatisfactory. It is suggested that a radical change be made along the lines contained in the Federal Code of Procedure and that a provision to the following effect be inserted in our Rules, which is substantially taken from that Code-

Any individual party to an action, or his employee, or any officer or employee of a corporation a party to an action, may be called by the opposite party as a witness at the trial, treated as an adverse witness, cross-examined and contradicted by other testimony, generally treated as though he had been called by the party opposed to the party examining him.

Consideration should be given, if this suggestion is adopted, to a corresponding amendment to the Evidence Act.

At the present time, if a person who is examined for discovery dies before the trial, his examination cannot be used on his behalf. This results in injustice and it is recommended, that if a party who has been examined for discovery, dies before the trial or is incapable of giving evidence, the whole of his examination may be put in as evidence on his behalf.

f-The time for service of appointment on solicitors should be shortened from twenty to ten days.

(The suggestion respecting the use of an examination for discovery being put in at the trial of a deceased person or who is otherwise incapable of giving evidence, as evidence on behalf of the person or the estate of the person so examined has met with some opposition. This suggestion is also taken from the Federal Rules and the proposed use of such evidence would seem to accord with elementary justice. 
The recommendation as to the amendment of the Evidence Act in this regard should be part of a complete revision of that Act which is badly needed.")

17. Affidavits.

A great deal of time is lost by reason of the fact that affidavits cannot be sworn until a Statement of Claim is issued-

a-There should be a provision for the taking of affidavits in an intended action if there is a bona fide intention to commence action.

b-There seems no reason for retaining the rule which prevents affidavits being sworn in the office of the solicitor on recordRule 352.

c-It is suggested, that this rule be eliminated and that affidavits may be taken in the office of the solicitor for the party.

$\mathrm{d}$-There seems no reason to believe that this would result in an increase in perjury, and it would eliminate a great waste of time.

18. Trials.

The Federal Rules provide that a Motion for a Non-Suit shall not prejudice the right of the defendant to call evidence if the motion is refused. There is some conflict of opinion amongst our judges as to whether or not an undertaking should be given by a party applying for a non-suit that he will not call evidence.

It is recommended that the American Rule be adopted and the practice settled in this way. (This change is also recommended by the Evershed Report with some safeguard as to Appeal.')

19. Originating Notice.

a-There should be provision that an accounting from a solicitor or delivery of documents could be obtained by clients by originating notice. This provision is now found in the Rules relating to costs. It should be eliminated there.

b-There should be a specific provision that judgments against executors or administrators be paid in due course of administration.

c-There should be no need to issue a writ of possession. The order of possession should be sufficient and the Sheriff should act upon it as though it were a writ.

20. Jury-Rule 277

a-the amount necessary to justify a jury trial except in specified cases, should be increased from $\$ 1,000$ to $\$ 2,000$. This would require an amendment to the Jury Act.

b-It is recommended that the jury should be provided in any Civil Action without cost to the litigant.

(These matters relating to Jury Trials should be of great concern to the practitioners. There are many cases where a jury trial is helpful. The expense of a jury in Alberta runs from $\$ 1,000$ upwards. There

- Vide the artlcle "Do We Need a Code of Bvidence". (1960) 38 Can. Bar Rev. 34: and the article "Evidence"-" A Fresh Approach-The American Uniform Rules of Bvidence" (1935) 37 Can. Bar Rev. 576.

I Evershed Report, op. cli. p. 104. 
is no good reason why the Crown should not bear all or a substantial part of this cost as is now the practice in many other jurisdictions. A litigant does not pay for the privilege of having a judge decide his case and there is no good reason why a litigant should have to pay for a jury -a right which is guaranteed by Magna Carta.)

21. Additions to the Rules.

There has been great difficulty in many jurisdictions by reason of the long delay in delivering judgments. It is suggested that the following provisions be added to our Rules of Court:

a-It shall be the duty of the Clerk of the Court in the district in which a trial is held to note the date of the completion of the trial. If judgment is not delivered within six months from the date, he shall send a memorandum of this fact to the trial judge, the Deputy Attorney General and the Chief Justice of the Trial Division; thereupon, it shall be the duty of the Chief Justice to direct a new trial before another judge.

(Additional thought will have to be given to this suggestion-for instance, who is to pay the cost of the first trial?)

b-Provision should be added to the Rules dealing with applications to commit for contempt for breach of an Order of the Court.

c-In the case of Moreau v. Baker, [1947] 1 W.W.R. 1098, Mr. Justice Ford delivering judgment of the Court of Appeal at the request of Counsel laid down the procedure to be adopted to obtain a certificate from the judge that a charge against land had ceased to be effective by virtue of the Limitation of Actions Act. This procedure should be adopted in the Rules. It is as follows:

The application need not be made by originating notice or by petition or even by Notice of Motion.

An application should be made to a judge who will direct service upon persons interested in opposing the application. Upon return of the application, unless there is an issue to be tried, he will dispose of the matter summarily. The certificate may be entered as an order under Extra-Curial Orders Act.

d-The provisions of English and Ontario Rules in regard to debenture actions should be embodied in our Rules which contain very sparse provisions as to the procedure in such cases.

(This last suggestion requires some amplification because the English Rule provides for the matter being delegated to a referee but unless the recommendation to appoint a master (who could also act as a referee) is adopted, we have no official who is a Referee. Mr. Saucier, however, has drafted changes in the rules which will make provision for this deficiency as it presently exists.)

\section{MR. SAUUCIER'S PROPOSED CHANGES}

\section{Changes in Rules Relative to Debenture Holders' Actions}

Rule 6 should be amended (i) by adding the words "and expressions" after the word "words" in the third line, (ii) by re-arranging the order of the following words and expressions into alphabetical order, and (iii) by adding thereto, in such order, the following:

"debentures' includes debentures stock and bonds;" 
'debenture holders' action' means any action for the enforcement of the security constituted by bonds, debentures or debenture stock of a corporation, or a trust deed or other like instrument securing the same;

Then, there should be added a new rule substantially similar to Order 51, r. 1-B of the English Rules, reading:

In a debenture holders' action where the debenture holders are entitled to the benefit of a charge by virtue of the debentures, or of a trust deed or other like instrument securing the same, or otherwise, and where the judge is of the opinion that there must eventually be a sale, he may in his discretion direct a sale before judgment, and also after judgment, before all the persons interested are ascertained, whether served or not.

Rule 1-A of Order 51 of the English Rules is substantially similar to Alberta Rule 578, which is included in Order XXXV, entitled "Sales of Real Estate". English Order 51 is entitled" Sales by the Court". It seems to me that the proposed new rule could be added, immediately following Alberta Rule 578, and changing the title of Order XXXV to "Sales by the Court".

(There are also various additional suggestions in the Evershed report which the writer submits merit adoption.):

(G) A party desiring to amend his pleadings should, in the first instance communicate with the other side by letter, stating the precise amendment he desires to make; an application to the Court should only be necessary if the other party objects to the proposed amendment and should be at that party's own risk as to costs.

(H) Documents not requiring to be served personally may be served by ordinary post.

(I) Where the title to an action is or has become long the full title need not be copied in all documents.

(J) The Court should be empowered to order that any document be admitted as an alleged fact of local or general public notoriety without regard to existing rules of evidence.

(These examples given by the Evershed Report are the date of the coronation or the declaration of war or peace or the name of the Derby winner.)

(K) The Court should be empowered to admit the transcript of a shorthand note taken by an official or other disinterested shorthand writer or any evidence given by a witness in previous proceedings where such witness is dead or on other grounds cannot reasonably be called as a witness.

(This is really a more extensive provision of one of the suggestions made by $\mathrm{Mr}$. Field, ante $16(\mathrm{e})$.)

(L) In a long case extending over several days or in the event of a case having to be adjourned the Judge trying the case should have power to direct that the whole or any part of the evidence shall be transcribed at the public expense and copies supplied to the Judge and each party.

(M) Any party shall be entitled to a transcript of the judgment given at the conclusion of the case at first instance at the public expense. 
(N) Statements made by witnesses to the police and proofs of police evidence in running down cases should be available to all parties in the litigation. ${ }^{8}$

(There should be added to the above-although this is not in the Evershed Report.):

(O) All hospital records, in cases involving damages in which the hospital care is relevant, should be available without the consent of the doctor in attendance, the hospital or the patient. This involves an amendment to The Hospitals Act which makes these records virtually unavailable.

Mr. Field's recommendations concluded with the following remarks:

22. Matters for Future Consideration.

There is a growing sultiment in favour of the adoption of the practice in the American Federal Court, of permitting the examination of witnesses before the trial. It is recommended that careful study be given to the advisability of embodying this procedure in our Rules. At the present time, there is not enough information available to justify any recommendation.

The Committee was unable to agree as to a recommendation as to pretrial conference. They were not effective in Alberta prior to amendment of the Rules and the order for directions became a mere matter of routine. They apparently are effective in the Federal Courts. We understand that British Columbia has recently adopted this procedure and it is recommended that a study be made of the successful practice there and that future action be taken if deemed advisable should the British Columbia experiment prove worthy of imitation.

Since the Federal Rules have now been in force some 25 years the time has surely arrived when both these suggestions should be embodied in our rules if the experience in the United States has found them beneficial.

\section{FURTHER REMARKS BY MR. HELMAN}

\section{The Right to Examine Witnesses}

Under the Federal Rules a party has the right to examine persons who have knowledge of the facts involved in the litigation and the very comprehensive rules relative to this are found under the heading "Depositions and Discovery". These provisions have been put in the Federal Rules as part of a scheme to break down the veil of secrecy which presently surrounds litigation. Knowledge of the evidence you have to meet may also lead to the settlement of many cases. The evidence of such witnesses may only be used for two purposes-(aside from the discovery of officers, and parties, etc.):

(1) It may be used to impeach the witness if he goes into the box to give evidence; or

(2) If the witness becomes unavailable by reason of death, illness or being outside of the jurisdiction or it is otherwise difficult to

8 Thls will require an amendment to the Vehlcles and Highway Traffic Act S.A. 1959. c. 93, 33. g1a-B1d: am R.S.A. 1860, c. 112, 8. 81c. 
obtain his presence at the trial, then the evidence so taken may be put in at the trial.

It will be seen from an examination of the Federal Rules that the purpose of the trial is that the Court should ascertain the fundamental facts and that both sides should know exactly what the other side can prove at the trial. The right to examine a witness may be a very useful right and it is strongly advocated in the United States in the various jurisdictions which have adopted the Federal Rules. ${ }^{0}$ As a corollary of the right to examine witnesses, one has to find out who the witnesses are and therefore on discovery, contrary to the rule that we have in Alberta, the party being examined has to disclose the names of persons that have knowledge of the facts. Indeed, the cases in the United States go further, and say that if after discovery the party locates additional persons having knowledge whose names have not been previously disclosed, such disclosures must also be made.

On the other hand, the Evershed Committee frowned on this suggestion and they stated that they had not been "persuaded of the advantage ... whereby the names still less the proof of each party's witnesses would be disclosed to the other side".

Finally, at the suggestion of Dean Bowker of the University of Alberta Law School, I wrote to Justice Clark about the examination of witnesses and the cost thereof. The following is an extract from his reply:

You speak of the extension of discovery of witnesses. Under the federal rules, discovery has always included the depositions of witnesses as well as parties; without either it would lose at least 50 per cent of its effectiveness. The expense initially is borne by the side seeking discovery-unless an order for advaneing some sums because of the hardship involved has been obtained from the court. The taxable costs, i.e., the court expenses which do not include the fees for the lawyers, will ultimately be assessed against the losing party, except in the relatively few cases where the court orders otherwise. The chief burden and expense of discovery by deposition is of course the expense of stenographers and their verbatim transcription of the testimony. Because of this, resort is at times had to written interrogatories as a substitute.

\section{Pre-Trial Conferences}

In British Columbia their Rules have adopted with only minor changes the provision contained in the American Federal Rules with regard to a pre-trial conference. The B.C. Rule reads as follows:

34(a) 1. In any action, cause or matter, the Court may, in its discretion, direct the solicitors for the parties themselves to appear before it for a conference to consider:

9 See "A Judge Looks at the Rules" by the Hon. Alexander Holtzolf, U.S. District Judge for the District of Columbia Federal Rules of Clvil Procedure, (West Pub. Co.. 1961) D. 1. His conclusion is:

"Broad and llberal discovery has completely revolutionized litigation in the Federal courts. As a result of the wide use of these remedles, most lawyers come into court for the trial thoroughly famillar not only with their own case, but also with the case of the adverse party. Surprise has been reduced to a minimum. Counsel frequently start the trial armed with depositions that elther eliminate a great deal of controversial matter, or else with evidence In such shape that it can be introduced much more prompily and effleaclougly than otherwlse might have been the case. Sparring at arm's length has been conslderably reduced. The important consideration is that all of these innovations tend to bring about a just declsion on the merits. There are still volces in the wilderness crying out against the ternors of broad discovery. The writer has observed however, that all too tre terrors of broad discovery. The writer has observed, however, that all too discovery when it is to their interest to do so. The walling and gnashing of teeth are gradually subsiding."

Discovery of Trial Preparations, Talne (1950) 50 Col. Law Rev. 1026.

The Federal Rules of Procedure (1938-1958). A collection of articles by outstanding nuthoritles ( 1958 ) 58 Col. Law Rev. $435-515$.

Proceedings of the Seminar on Procedures for Effectlve Judicial Adminlstration held at the Southwestern Lebal Centre, Dallas, Tex. 1961 at p. 280 and seq. 
(1) The simplification of the issues:

(2) The necessity or desirability of amendments to pleadings:

(3) The possibility of obtaining such admissions as will facilitate the trial:

(4) Such other matters as may aid in the disposition of the action, cause, or matter.

2. Following such conference the Court may make an order reciting the results of the conference and giving such directions as the Court may consider advisable; and such order, when entered, shall control the subsequent course of the action, cause, or matter, unless modified at the trial or hearing to prevent manifest injustice.

3. The Judge who conducts a pretrial conference in any action, cause, or matter shall not be deemed to be seized of that action, cause, or matter which may therefater be tried by him or by any other Judge of the Court.

There have been a vast number of articles written with regard to pre-trial conference. The consensus of opinion is that such a conference fills a useful place in being helpful to the Court and to the clients, as well as the lawyers, in arriving at a simplification and crystallization of the factual basis of the issues raised in the lawsuit.

The writer would refer you to a book by Harry D. Nims on Pre-Trial and, if the book is not available to you there is an excellent article by Mr. Nims on the same subject in (1947) 25 Canadian Bar Review at page 697. A most helpful article is by Judge Yankwich. ${ }^{30}$ He starts out his article by saying:

Pretrial is now generally considered one of the accepted means of obtaining the fullest possible knowledge of the issues and facts before trial. It and the whole system of discovery help us find the truth, and that is what a lawsuit is intended to do under our system of justice under law.

In view of the general acceptance of pretrial procedure, I can best help the cause further by emphasizing from my own judicial experience some of the beneficial results of pretrial in seeking to attain its objectives.

The summary and conclusion of Judge Yankwich is in the following language:

Pretrial propertly administered, can be a useful tool for the administration of justice. It is the aim of litigation to achieve social peace, and this can best be achieved in an adversary proceeding in which the court seeks to ascertain which way justice under the law lies. For a long time the great emphasis has been on the 'sporting theory' of justice, a theory that stresses the lawsuit as a game with the judge as an umpire awarding the prize to the more skilful. This principle is outmoded. We all now see in a lawsuit a means to achieve justice under law. The judge in a federal court is 'the governor' of the trial. The pretrial procedure enables him to exercise his function with greater efficiency.

The writer also enquired from Judge Clark about his present views on this subject and he wrote:

The pretrial conference as authorized (but not made mandatory) by Federal Rule 16 has had a rather spectacular success in the hands of skilled judges in advancing litigation toward its conclusion and in inducing settlements of cases. This has led to a demand by many enthusiasts for its extension to all civil cases. Frankly as an old and original exponent of pretrial, I am rather disturbed by this, as I fear that it can be pressed too far on unwilling parties and judges. I believe it highly useful in certain types of cases and with judges possessing a personality and skill to make use of it. But I do not myself believe it is an automatic and self-operating reform which any innocent fledgling can use to advantage. In skilled hands it can expedite many a case wonderfully; compare the English summons for directions, which it a little resembles. In unskilled and recalcitrant hands, however, it may be a burden and a delaying step.13

10 Chlef Judge of the United States Distrlct Court for the Southern District of California, (1958) 58 Col. Law Rev. 470.

11 See also the statement by Judge Clark in the 1961 Seminar at Dallas. Tex. op. cit. and hls article "Objectives of Pre-Trial Procedure"-(1956) 17 Ohio S.L.J. 160 at 163. 
You will observe that Mr. Field points out that in Alberta we originally had what was called an order for direction which is something that is still found useful in England, but it is not now contained in our present Rules because it was found to be a matter of routine and that we could and do get along without it. The order was taken out at too early a stage.

The Evershed Committee considered the Federal Rule respecting Pre-Trial Conferences and also a somewhat similar procedure in use in the State of South Australia. The general idea of a pre-trial conference was not endorsed by the Evershed Committee nor indeed did they endorse verbal examinations for discovery. Both were discarded on the ground that they would add too much expense to the cost of litigation because the attendance of Senior and Junior Counsel and probably the solicitor would be required both at the pretrial conference and at discoveries. As part of the function of the Evershed Committee was to try and cut down the cost of litigation its refusal to accept both pretrial conferences and verbal discoveries might be justified on this ground.

However, the Evershed Committee thought that what was not obtained in a pretrial conference could be arrived at by strengthening their provision respecting the order for direction. They ended up with a provision very similar in effect to the provisions contained in the Federal Pre-trial rule but saving expense by being dealt with by the Master in Chambers. ${ }^{12}$

\section{CONCLUSION}

The writer's conclusion from his study is that procedural law is not an end in itself. It is but a means of attaining justice. We must be willing therefore to be flexible in our use of this tool, we must be willing to try new ideas and perfect new techniques and to thereby constantly ensure that the law is always capable of meeting the current requirements of our ever changing society.

The bringing out of a model set of Rules of Court would be a most rewarding work to be undertaken by the Commissioners on Uniformity of Legislation. 